\title{
As ruínas da cidade grande: imagens da experiência urbana na literatura brasileira contemporânea
}

\section{Ruins of the metropolis: images of urban experience in Brazilian contemporary literature}

\author{
I dilva Maria Pires Germano* \\ Professora Adjunta do Programa de Pós-Graduação em Psicologia da Universidade \\ Federal do Ceará - UFC, Fortaleza, Ceará, Brasil.
}

\begin{abstract}
Resumo
A prosa de ficção brasileira contemporânea revela que a cidade tem sido objeto privilegiado de reflexão e imaginação poética. Escritores como Rubem Fonseca, Caio Fernando Abreu, Chico Buarque, João Gilberto Noll e Luiz Ruffato exploram os aspectos desagregadores da vida na metrópole e seus efeitos sobre os processos de subjetivação, sensibilidades e formas de convívio social. Tal literatura focaliza a cidade em cenários, personagens, enredos e, sobretudo, formas de narrar, que parecem evocar a dificuldade de traduzir a cidade que hoje habitamos. Este trabalho examina a construção simbólica da experiência urbana brasileira, analisando as representações da cidade numa seleção de textos, a partir da noção de "literatura de subtração" (FARIA, 1999). Discutimos como esses textos encerram percepções desencantadas, evocando a perda da cidade moderna sonhada. O escritor, ao estranhar seu próprio espaço e tempo, deslinda as faltas, as ruínas e as patologias da vida urbana em tempos de modernidade tardia.
\end{abstract}

Palavras-Chave: Experiência urbana, Literatura brasileira, Cidade na ficção contemporânea.

\begin{abstract}
Contemporary Brazilian fiction reveals the city has been a privileged object of thought and poetic imagination. Writers such as Rubem Fonseca, Caio Fernando Abreu, Chico Buarque, J oão Gilberto Noll e Luiz Ruffato explore the disaggregating aspects of metropolitan life and its effects on processes of subjectivization, sensibilities and modes of social gathering. This literature focuses the city in scenarios, characters, plots and, specially, narrative forms that seem to evoke the difficulty of translating the city we inhabit nowadays. This paper examines the symbolic construction of Brazilian urban experience, analyzing the representations of the city in a selection of fictional works in the perspective of a "literature of subtraction" (FARIA, 1999). We discuss how these works elaborate disenchanted perceptions associated with the loss of the dreamt modern city. While estranging his own time and space, the writer unfolds the losses, ruins and pathologies of urban life in late modern times.
\end{abstract}




\section{Keywords: Urban experience, Brazilian literature, City in contemporary fiction. \\ I - A ficção brasileira contemporânea e os dilemas da representação da experiência urbana}

Críticos e teóricos da literatura vêm discutindo uma série de transformações visíveis na ficção brasileira produzida a partir das últimas décadas do século XX (PELLEGRINI, 1994; LOBO, 2000; SÜSSEKIND, 2001). As transformações observadas no plano textual, vistas muitas vezes como tendências contemporâneas, envolvem desde os modos de figuração do tempo e espaço, a caracterização das personagens e enredos até as constantes estilísticas que parecem substituir formas canônicas encontradas nos textos produzidos na primeira metade do século $X X$, ou antes. Uma das mudanças operadas pela ficção que surge especialmente a partir dos anos 70 é o foco dominante no mundo urbano (especialmente as contradições das grandes cidades brasileiras globalizadas), em detrimento de temáticas consagradas na tradição das letras brasileiras, como a problemática "nacional". De fato, o conceito de "nação", como muitos outros de inspiração universalista, oriundos das grandes narrativas da modernidade, passam a ser desconstruídos não somente na teoria crítica, mas também na criação literária. A suspeição dos valores de autonomia, coerência, racionalidade e universalidade do sujeito, alimentada hoje na filosofia contemporânea, apresenta-se singularmente na experimentação estética, que também segue em direção a uma valorização da heterogeneidade, diferença, fragmentação, indeterminação, alteridade.

$\mathrm{Na}$ literatura brasileira contemporânea, seja nos elementos específicos que enformam o enredo (personagens, cenários, ações, coordenadas temporais e espaciais), seja nos recursos expressivos adotados, a ficção não deixa de figurar, de modo revelador, a atmosfera de ceticismo quanto às possibilidades de representação segura do mundo. Parte importante desta ficção heterogênea ${ }^{1}$ aprofunda a disposição modernista de dissecar os mecanismos linguísticos que constroem a realidade, voltando-se sobre si mesma e subvertendo os modelos realistas que estão na base da história do gênero romanesco. Seja no abandono das intenções miméticas, seja num peculiar "retorno do real" (que vigora em textos de matiz documentarista e de denúncia), tal ficção convoca o leitor a abandonar suas expectativas arraigadas de leitura - da obra e do mundo - exigindo-o abertamente como co-autor, dificultando-Ihe a recepção e produzindo momentos de estranheza e desalojamento.

A ficção contemporânea é acompanhada de um discurso auto-reflexivo em que o escritor questiona o papel político da literatura na sociedade de consumo, diante do poderio da indústria cultural, muitas vezes moldando essa autocrítica como objeto de sua escrita. No campo artístico, no exterior e no Brasil, discutem-se, sob novas perspectivas, questões como o conceito e do papel da arte e do artista no capitalismo tardio, a relação 
entre arte e público, os meandros da ideologia (que afetam as práticas aparentemente mais vanguardeiras) e as interações entre linguagens e campos de saber (FOSTER, 2005). Debatem-se, ainda, as possibilidades de representação estética de uma socialibilidade marcada pela compressão do tempo-espaço (HARVEY, 1994), por um declínio do sentido histórico e utópico e pela generalizada perda de referências para a ação.

$\mathrm{Na}$ crítica literária brasileira, especialmente aquela voltada para a ficção do fim do século $X X$, cujo tema privilegiado é a cidade, cunha-se a noção de "literatura de subtração", isto é, uma literatura obrigada a figurar a perda da cidade ideal - racionalizável, controlável e unificável - do discurso moderno (RENATO GOMES, 1994, 1998, 1999; ALEXANDRE FARIA, 1999). Seja descrevendo caleidoscopicamente as cenas da vida urbana, sua heterogeneidade, as cruezas da violência e do medo e os fragmentos do presente avassalador, seja revisitando nostalgicamente a cidade perdida e o trabalho da memória e do sonho, os textos evocam a distopia, o sentido penoso de se viver na metrópole e de dizê-la. Como ler, interpretar e comunicar a experiência urbana nesse cenário de perda das certezas, de presentificação do tempo, de questionamento das possibilidades da narrativa?

Pois a vida nas grandes cidades em grande parte do mundo contemporâneo partilha formas de subjetivação e sociabilidades semelhantes - forjadas pela propaganda, pelos meios audiovisuais, pelos shopping centers, pelo consumo (ou a impossibilidade do consumo) de marcas internacionais padronizadas - que acenam para uma vivência esvaziada do tempo e do espaço. Beatriz Sarlo (2006) assinala como a experiência urbana a cada dia se desvincula das tradições favorecendo um espaço e o tempo "sem qualidades". A cidade atual vai perdendo seu antigo "centro", sendo este substituído pelos shoppings, uniformes em sua arquitetura, suas mercadorias e suas marcas e funcionalmente desapegados da história e das tradições da cidade. No que tange às sensibilidades modeladas nos jogos de videogame, no zapping e noutras práticas obedientes à lógica do mercado, a combinação de velocidade e de esvaziamento da narração e do sentido histórico parece configurar o signo de uma época, ilustrado metonimicamente nas culturas urbanas juvenis:

Se ha dicho que los vídeo-games son um "carnaval de significantes". Así se interpreta el vaciamento de narración que realizan incluso aquellos juegos que, por su título y por el sistema de personajes, prometen uma historia. En realidad, el cumplimiento de esa promesa deja indiferente al jugador que no comienza el juego para ver si este le revela el desenlace de una ficción casi inexistente, sino para producir uma desenlace no ficcional en su duelo con la máquina. Los signos que evocan personajes, oposiciones, jerarquías, enemigos y ayudantes [...], prueban que se puede tener un sistema de personajes sin tener historia. I gualmente hay acción sin narración en cada una de las 
unidades del juego: algo acerca los video-games al tedio de um infinito cíclico, como un dibujo animado del gato y del ratón o del pájaro loco. No se necesita recordar la unidad anterior para pasar a la siguiente. Lo que si existe [...] es um tema [...]. Tema sin narración, tema em estado primitivo antes de la peripécia, de los desvios, de las líneas secundarias. Entonces: tema y significantes. (51-52)

Como organizar narrativamente os sentidos fragmentados de uma metrópole contemporânea, que não mais se estruturam em torno de marcas históricas e territoriais aspirantes a uma unidade nacional? Canclini (2001), do ponto de vista do antropólogo urbano, revela preocupações similares sobre os óbices de narrar as megacidades latinoamericanas, multiculturais e de crescimento desordenado, com retóricas do passado ainda presas à representação realista de um território e de uma história:

\begin{abstract}
As grandes cidades, dilaceradas pelo crescimento errático e por um multiculturalismo conflitante, são o cenário em que melhor se manifesta o declínio das metanarrativas históricas, das utopias que imaginaram um desenvolvimento ascendente e coeso através do tempo. Mesmo nas cidades carregadas de signos do passado, como a capital mexicana, o encolhimento do presente e a perplexidade diante do devir incontrolável reduzem as experiências temporais e privilegiam as conexões simultâneas no espaço. ( $p$. 154)
\end{abstract}

$O$ relato do flâneur, daquele que deambula pela cidade em processo de modernização no fim dos oitocentos e no início do século $X X$, não parece às vezes adequado para abarcar com mínima coesão a pluralidade de discursos e práticas que modelam a cidade integrada aos circuitos transnacionais de produção, consumo e comunicação. Se o flâneur é aquele observador que, em seu passeio e em sua escrita, ainda consegue organizar e interpretar as transformações urbanas emergentes (em virtude de sua posição liminar, nem subjugado pela cidade grande, nem pela classe burguesa), essa tarefa mostra-se cada vez mais inexequível, pois seria necessário articular os múltiplos discursos e narrativas locais, nacionais, transnacionais que fazem hoje a experiência urbana. Novamente uma imagem da videocultura serve de metáfora para a cidade tardo-moderna: "Narrar é saber que já não é possível a experiência da ordem que o flâneur esperava estabelecer ao passear pela metrópole do início do século. Agora a cidade é como um videoclipe: montagem efervescente de imagens descontínuas" (CANCLINI, 2001:155). Para quem deseja compreender a metrópole transnacional, a busca de uma lógica temporal que unifique a cidade (uma narrativa com começo, meio e fim) parece dar lugar a uma abordagem das relações simultâneas que ocorrem num mesmo espaço. 
A formação da subjetividade moderna, objeto de teóricos como Benjamin e Simmel, esteve associada à emergência de um tipo humano peculiar e historicamente específico, obrigado a enfrentar ambivalentemente os excessos da cidade mediante uma atitude simultaneamente sintonizada e distanciada das múltiplas interpelações urbanas do consumo, das ideologias, dos poderes e outros estímulos. Para Simmel (1900/1979), a impessoalidade do dinheiro, característica da sociabilidade moderna, representou em princípio a valorização da individualidade, da autoconsciência, da autonomia. Contudo, a cultura exacerbada do lucro levou à destruição outras sociabilidades marcadas pela intimidade e pessoalidade e sua substituição por uma atitude blasé - "reflexo subjetivo da economia do dinheiro completamente interiorizada" (p.16). Para se acomodar às forças externas que tendiam a nivelar e uniformizar os indivíduos, a personalidade metropolitana tornava-se mais calculista e indiferente, menos sentimental. A figura do flâneur de Benjamin e do metropolitano blasé de Simmel encontram eco na ficção moderna que trata dos efeitos da cultura do dinheiro. Para Keohane (2002), uma personagem ideal-típica da subjetivação moderna seria Bloom, de Joyce, que representaria as qualidades heróicas e utópicas do homem moderno que luta para manter a autonomia contra as avassaladoras forças impessoais da modernidade.

É assim que o homem moderno, como Bloom, pode ser visto como um herói que desenvolve formas particulares de resistência e autonomização contra os poderes disseminados que levam à padronização e à submissão. Embora imerso na multidão e sujeito ao poderes soberanos da sociedade massificada, ele reflete sobre o mundo e sobre si mesmo, resistindo a se levar pela maré, capaz de escolhas e de evadir-se das múltiplas demandas perceptuais, ideológicas e de consumo que pululam na vida urbana. Essa atitude de resistência configura, para alguns, o exercício deliberado de liberdade individual, um "cuidado de si" ou "esforço sistemático para conhecer a si mesmo, para cultivar-se, para dominar os apetites que ameaçam engolfá-lo" (KEOHANE, p. 32). Como Bloom, que se coloca em múltiplas posições e pontos de vista, negociando seu caminho através da cidade e ciente da pluralidade de mundos e percepções, o homem moderno prototípico pode ler e compreender a cidade a partir de seus encontros com a alteridade. Tais encontros o levam a pensar os limites de seu próprio ângulo de visão.

Algumas questões se colocam face à exacerbação das condições de produção e consumo na contemporaneidade: existem hoje condições de possibilidade para o cultivo de si, para o discernimento auto-reflexivo desse homem cada vez mais mergulhado nos poderes invisíveis da sociedade de controle? Como as personagens de ficção contemporânea forjam o homem de hoje, como representam sua relação com a cidade e suas formas e capacidades de enfrentamento dos poderes da cultura de 
massas atual? Como se dá a mobilidade das novas personagens idealtípicas contemporâneas? Em que medida permanecem ou se modificam os flaneurs da ficção no que concerne a sua resistência ao poder, ao seu perfil reflexivo e seu talento emancipatório? Que figuras ideal-típicas parecem mais representativas da experiência urbana em tempos de capitalismo transnacional?

O escritor hoje, mais que nunca, encontra-se diante do desafio de lidar com os universos simbólicos plurais e desconexos que compõem a vida urbana, simultaneamente como objeto de sua mirada estético-cognitiva e como teia de subjetivação em que está ele mesmo enredado, armando seu olhar e ponto de vista. Sendo fruto de uma época que operou transformações importantes sobre as formas de entendimento e sentimento do espaço e do tempo, a ficção contemporânea refrata as tensões da experiência contemporânea e os sentimentos ambivalentes dos habitantes dos grandes centros, instados a posicionar-se moralmente diante do que se tornaram a cidade e a cidadania. Descrevendo cenários, situações e emoções que experimentamos cotidianamente nas metrópoles, relatando episódios banais ou insólitos, os escritores vão promovendo modos de conhecimento das coisas, não simplesmente objetos de contemplação, fruição ou adoração, mas versões e visões de mundo, formas de "organizar as coisas". Muitas versões poéticas atuais tendem a assinalar a ilegibilidade da cidade e o vazio da experiência social, que parecem corresponder aos impasses enfrentados pelo intelectual contemporâneo na reflexão sobre os rumos da modernidade e sobre as possibilidades da atividade criadora: determinismo/agência, transformação/adaptação, celebração/repúdio.

Embora herdeira da tradição modernista, a literatura das últimas décadas apresenta alguns traços dispersos que destoam do perfil modernista "canônico" (ou melhor, dos valores da modernidade literária no ocidente), convidando a uma abordagem diferenciada de suas características, seja em termos de periodização, de estilo ou de posicionamento político e ideológico ${ }^{2}$. Para alguns críticos, a principal oposição entre a arte que se faz hoje e a que se fez nas primeiras décadas do século XX não reside no debate estético propriamente dito (pois há entre elas muitos pontos compartilhados e indistintos), mas numa tomada de posição em relação aos princípios mais amplos do "projeto da modernidade", especialmente aqueles envolvidos na dominação e no poder-em-representação, destacados pela crítica pós-estruturalista, pós-colonialista, pelos movimentos feministas, étnicos e ecológicos que passaram a dominar a cena intelectual desde os anos sessenta.

Problemática importante nas ciências sociais e humanidades, a "representação" ou "referenciação" ao mundo (e aos outros textos) ganha foco no pensamento e na atividade artística, motivando a adoção de mecanismos que alteram, de modo mais ou menos incisivo, as 
pressuposições realistas convencionais. Se a representação realista já mostrava seus limites no alto modernismo ${ }^{3}$, sua dissolução tende a concretizar-se numa vertente de experimentação literária tributária de perspectivas ontológicas e epistemológicas relativistas, onde, sob variados graus de radicalismo, se nega a existência de uma realidade com propriedades definidas e cognoscíveis e se defende a descontinuidade entre a narrativa e o real vivido.

À semelhança das reflexões construcionistas na historiografia, nas ciências sociais, psicologia social e outras disciplinas atentas à modelação linguística de seus objetos, o discurso literário contemporâneo pensa os efeitos de realidade construídos pela linguagem literária. A trajetória do romance moderno aos nossos dias exibe a radicalização da posição reflexiva ou metaficcional, associada ao modernismo, como alternativa ao relativismo e à incerteza quanto à possibilidade de se afirmar algo sobre o mundo. Como diz Vera Figueiredo:

o romance hoje se constrói, tematizando e, muitas vezes ironizando, seu próprio impasse: se o discurso não revela uma verdade última, se a própria referencialidade é um efeito de figuração, se não há nenhuma verdade oculta na realidade esperando para ser captada pela arte, que pode a literatura atual fazer senão voltar-se sobre si mesma? Levando ao extremo a reflexividade da arte moderna, indagará, então, dentre outras coisas, sobre o seu lugar num mundo, onde o texto literário, fechado em si mesmo, condena-se a uma gratuidade estéril. (2001)

De fato, especialmente a partir dos anos 70 do século $X X$, o próprio conceito de narrativa ganha novos enfoques incorporando as transformações nos modelos narrativos operadas pela ficção mais experimental. Vale lembrar, como observa Olinto (s/d) que noutros campos, como na historiografia, tais mudanças na forma narrativa passaram a inspirar propostas acerca do modelo mais apropriado para acessar o passado e o presente. A noção estrita de narrativa, isto é, aquela de tradição todoroviana - fundada numa idéia de sequência lógica e temporal de movimentos de equilíbrio (equilíbrio inicial - perturbação ou desequilíbrio- transformação ou resolução- novo equilíbrio), deixa de dominar o cânone ao fim do século XX para dar lugar a formas diferenciadas de narração. Muitas vezes, tais formas alteram radicalmente a experiência de "contar uma história" e com isto, a experiência de como se lê uma história, isto é, o modo como compreendemos "do que se trata" e como o fruímos. As novas narrativas provocam um sentimento de descentralização e pluralidade no leitor, refratando, mas também ajudando a configurar, tal sensibilidade na cultura contemporânea.

Para examinar como os escritores recriam a caótica experiência urbana brasileira ao final do século $\mathrm{XX}$, foram escolhidos alguns textos cuja 
temática privilegia a cidade e seus habitantes. São textos aos quais podemos lançar questões acerca dos modos como o discurso social atual, suas práticas, seu pensamento e suas sensibilidades encarnam-se em artefatos culturais como romances e contos. Pressupõe-se que tais textos podem nos ensinar algo sobre como escritores brasileiros no fim do século $\mathrm{XX}$ experimentam as transformações do seu espaço-tempo, fixam-Ihe os traços e os comunicam expressiva e persuasivamente para seus leitores. Embora a criação literária não tenha necessariamente interesse programático de fornecer inteligibilidade aos fatos históricos, posto que trabalho imaginativo, ela é capaz de abrir horizontes de sentido que ora estranham visões consolidadas sobre o real, ora familiarizam o concebido como exótico.

A experiência das ruas, do fluxo incessante de corpos e automóveis, da compra e venda, do ruído, dos espaços de trânsito veloz e paradoxalmente solitários, a vida urbana pulsante e moribunda, visível e invisível, em sua presença e ausência eloquentes é criada de modo a iluminar um campo de significações quase sempre dolorosas. Metamorfoses da vida "real", os quadros urbanos modelados por certos textos ficcionais obrigam o leitor a suspender sua passividade tanto diante da vida quanto do texto. Nem pura imaginação, nem mimese de uma realidade pré-existente, a ficção transita numa espécie de entre-lugar que potencializa a reflexão de si e do Outro sem que o leitor se dê conta.

Não é nossa intenção aqui revisar todo o debate entre as teorias do modernismo e suas variantes "pós", mas argumentar que, independente de quaisquer críticas quanto ao valor do debate e mesmo à pertinência dos conceitos (especialmente quando aplicados à criação literária), parece-nos legítimo fazer certas perguntas: como as obras de ficção produzidas nas últimas três décadas no Brasil modelam a matéria social que fundamenta sua atividade criadora? Como encarnam a configuração histórico-cultural do seu tempo? Como narram as novas sensibilidades, formas de subjetivação e relação com a alteridade que se observam nas práticas cotidianas? Como dialogam com outros saberes e práticas e como definem seu próprio estatuto de conhecimento e ação? Como certos dilemas da atividade literária hoje tocam dilemas mais abrangentes das ciências humanas?

Estas são algumas questões que gostaríamos de discutir nesse momento, a partir da leitura de Estorvo, de Chico Buarque, Hotel Atlântico, de João Gilberto Noll, Eles eram muitos cavalos, de Luiz Ruffato e alguns contos de Caio Abreu e Rubem Fonseca.

\section{Fábulas citadinas e estratégias de narração em tempos de distopia}


A leitura de contos e romances brasileiros contemporâneos revela a dificuldade de representação da vida urbana numa época de intenso mal estar com a cidade. Emblema da vida contemporânea em suas dimensões de diversidade, tensão e incomunicabilidade, a cidade torna-se protagonista de muitas obras de escritores brasileiros dos últimos trinta anos. O espaço físico e humano da cidade desdobra-se em constantes temáticas e tendências narrativas que urdem os imaginários urbanos atuais no Brasil. Os textos incluem elementos e procedimentos tais como o foco em personagens andarilhas, sem compromisso e sem destino; a onipresença dos não-lugares e os espaços degradados e disfóricos; a aceleração do passo do flâneur, tornando circular o trânsito na cidade (com a evocação de que se vai a lugar nenhum); os cenários e ações envolvendo medo e violência, de modo a evocar as patologias e transgressões individuais e coletivas; as relações conflituosas de alteridade, num espaço físico e subjetivo que força a partilha do território urbano; a focalização na perspectiva do Outro assujeitado (pobre, marginal, migrante, estrangeiro, delinquente, homossexual) e, atravessando todos esses elementos, a tematização de uma cultura de consumo que imprime sua lógica a toda e qualquer esfera da vida.

Diante da coexistência e proximidade de mundos heterogêneos, numa época de encurtamento das distâncias, retração do tempo, multiculturalidade, fragmentação do "eu", parece até que a ficção direciona suas preocupações para o estatuto ontológico da realidade - "o que" a realidade é - e não tanto como se pode conhecê-la. (HARVEY, 1994). Na perspectiva de uma ontologia relativista, constituída de "múltiplas realidades", onde se discute ardentemente a legitimidade das interpretações e representações ao ponto extremo de abolir a possibilidade de integração dos acontecimentos e polifonias, a ficção e a teoria literária traduzem essas problemáticas e novas sensibilidades no tratamento da matéria narrada. Desta forma, alguns textos ficcionais optam por abordar a realidade urbana mediante a colagem ou coleção de microhistórias, como instantâneos fragmentados cuja legibilidade prescinde de uma focalização específica. A reunião de tais historietas ou contos, narrados a partir de perspectivas multivocais, "abrem" o texto a cognições e afetividades plurais (e a horizontes éticos ampliados), que revelam, para além dos simples acontecimentos, um mundo de tendências, práticas e sistemas de significação duradouros, atitudes mentais, formas compartilhadas de viver, sofrer e sonhar no espaço e tempo do Brasil contemporâneo.

Texto exemplar neste sentido é o Eles eram muitos cavalos (2007), de Luiz Ruffato, romance que narra o vasto espectro de acontecimentos cotidianos, quase sempre dolorosos e cruéis, no espaço de um dia na cidade de São Paulo. A estrutura do romance é a própria cara da metrópole, composta por uma sucessão de pequenos contos, cartas, 
orações, previsões metereológicas, horóscopos, anúncios de jornal, diploma, cardápio e mesmo uma página negra quase ao fim do livro. A apresentação desses discursos plurais e dispersos ao modo de um videoclipe fortalece a imagem da cidade como mosaico, onde se justapõem (e quase sempre colidem) relatos, imagens, tempos e espaços distintos. Homens e mulheres de todas as idades, de todas as ocupações e condições sociais, e mesmo um cão protagonizam os breves instantâneos que articulam sintaticamente a vida na metrópole desigual. Estão lá os destinos de gente mais que comum: a dona de casa cansada do marido e da vida difícil, a jovem balconista prestes a morrer num assalto, o rapaz desanimado que vai à décima entrevista de emprego em dois meses, o pregador que enfrenta a indiferença e a derrisão dos transeuntes, a mãe pobre enlouquecida com a desaparição da filha pequena, os operários que se esborracham do alto do edifício pouco depois de planejarem ir ao jogo de futebol no domingo, a aspirante a atriz que bebe enquanto aguarda alguma oportunidade, a mulher abandonada que liga pateticamente para a rival mais jovem, o ladrão que imagina o que e como dar o presente do Dia das Mães, o empresário rico que fala mal do país e da cidade no heliponto, o pequeno funcionário que arranja mulher para figurões, o índio alcoólatra que segue sem rumo após a morte do dono do bar, a professorinha que chora após a horta da escola ser destruída por vândalos... As trajetórias dessas personagens comuns configuram quadros dramáticos e pungentes do cotidiano da cidade que realçam o sentido de perda, melancolia e impotência.

A expressão dos múltiplos discursos que se enredam na cidade é tratada de forma inovadora por Ruffato que trabalha exaustivamente a linguagem, inclusive com recursos visuais como negritos, itálicos, sublinhados, mudanças de tipos e outros. Uma ilustração dessas estratégias pode ser visualizada no trecho abaixo que mostra as várias vozes que se ouvem num heliponto e que remetem não somente para a intimidade de cada falante, mas também para os códigos ideológicos que orientam a conduta de tipos abastados na cidade de São Paulo:

- Não sou insensível à questão social irreconhecível o centro da cidade hordas de camelôs batedores de carteira homens-sanduíche cheiro de urina cheiro de óleo saturado cheiro de a mão os cabelos ralos percorre (minha mãe punha luvas, chapéu, salto-alto para passear no viaduto do chá, eu, menino, pequenininho mesmo, corria na) este é o país do futuro? deus é brasileiro? Ontem onde um manancial hoje uma favela onde ontem uma escola hoje uma cadeia onde ontem um prédio do começo do século hoje um três dormitórios suíte setenta metros quadrados - o jipe atravessado no meio da rua o ferreira deu uma freada os seguranças vinham atrás saíram atirando o ferreira deu ré fugimos pela contramão passei uma semana à base de são imigrantes são baianos mineiros nordestinos gente desenraizada sem amor à cidade para eles tanto (vocês e seus quatrocentos anos! vão 
se) fez é uma cidade magnífica os minaretes (podre, a cidade) ( $p$. 39-40)

Os "contos" podem ser lidos separadamente, mas a sua leitura na sequência proposta no livro permite ao leitor reencontrar algum sentido ao que chamamos de cidade. Do atomismo e segregação das historietas, o leitor tende a reconstruir uma unidade a estes fragmentos dispersos, uma unidade essencialmente negativa, a da perda e do vazio existencial: conscientes ou não, as personagens enfrentam o colapso do sentido. Resignados ao ritmo veloz, às pressões totalizantes da cultura do consumo, à impotência da condição excluída, aos ciclos de trabalho alienante, às perdas de balizas e de sonhos, os heróis de Eles eram muitos cavalos testemunham apocalipticamente o fim da cidade, que há muito perdeu a esperança e os sonhos prosperidade e equidade. Hoje a experiência urbana é infernal, apogeu de todos os tipos de desvios econômicos, políticos, sociais e morais, tornando a cidade um lugar de alienação, sofrimento e castigo. De fato, o texto de Ruffato exibe como epígrafe trecho do Salmo 82 - "Até quando julgareis injustamente a causa dos ímpios?"- que evoca, no contexto da vida urbana atual, a subversão dos princípios de civilidade, a escravidão da população à máquina do lucro e do consumo e a negligência da cidade, especialmente dos mais pobres e indefesos, pelas autoridades e setores mais capazes de protegê-la. Noutra passagem, solicita a leitura do Salmo 38, cujo sentido de súplica volta-se agora para a cidade doente que não merece afinal o tratamento que recebe. Tais passagens bíblicas no texto evocam a frágil condição em que se encontram os indivíduos anônimos na cidade-sociedade da periferia do capitalismo. Misto de súplica e denúncia contra as forças e dispositivos que mantêm subjugados ao consumo as mentes e corpos, especialmente em condições de injustiça e desigualdade, o texto exprime a tonalidade de desencanto e prostração que se percebe nas queixas cotidianas de quem vive nas metrópoles do país. A dedicatória a Cecília Meireles vem acompanhada de trecho de "Os cavalos da Inconfidência" "Eles eram muitos cavalos, mas ninguém mais sabe os seus nomes, sua pelagem, sua origem..." - que, no contexto do romance, é altamente sugestivo do fardo carregado silenciosamente por homens e mulheres anônimos, "testemunhas sem depoimentos diante de equívocos enormes"

Os processos de subjetivação contemporâneos também podem ser figurados na construção das personagens, especialmente na sua relação com os espaços urbanos. Um desses perfis é o do andarilho, indivíduo que percorre o espaço da cidade, muitas vezes, sem rumo, sem compromisso, sem referências fixas, alegorizando a condição desterritorializada do sujeito atual. As trajetórias também ocorrem entre cidades, os protagonistas migrando de lugar para lugar, seu destino se fazendo na travessia de cenários e figuras humanas voláteis, ao sabor do acaso e das 
sensações. Pouca bagagem e minguados sonhos são comumente associados à experiência contemporânea de perda das utopias que a modernidade alimentou. Nesta vertente de textos, o trânsito pela cidade ou entre cidades pode ser vertiginoso (como num filme de ação), o protagonista em fuga de algo ou alguém que lhe atormenta, seja fora ou dentro de si.

Esse nomadismo, carregado de uma atmosfera angustiante, ronda os protagonistas de Estorvo(1991), de Chico Buarquee de Hotel Atlântico(2004), de João Gilberto Noll. Mesmo diante de um texto de matiz onírico ou quase surreal, o leitor não deixa de identificar a atmosfera romanesca com suas próprias experiências de angústia no moinho da metrópole. O medo e o mal estar podem ser difusos (o herói de Estorvofoge de um homem que vislumbrou pelo olho mágico e que parece vagamente conhecido e perigoso) ou bem concretos, embora nem sempre inteligíveis (como em Hotel Atlântico, quando o protagonista é perseguido por homens armados que Ihe deram carona).

Em Estorvo, a narrativa do herói anônimo (imagem do indivíduo serializado e massificado) é um périplo em torno da grande cidade polifônica que soterra a infância do protagonista nos desvãos da memória, do sonho e da fantasia. O texto circular, praticamente intraduzível em termos de enredo, trata do trânsito vertiginoso de um homem que acredita estar sendo perseguido por alguém vagamente familiar, tal como Ihe pareceu no olho mágico. Em suas andanças na cidade, os eventos com traços oníricos - sucedem-se sem que o narrador possa efetivamente conferir-Ihes sentido. Contudo, o que mais salta aos olhos é a evocação paralela de um mundo privado e de uma cidade perdida para sempre. A cidade da infância do narrador-andarilho é a cidade do antigo sítio da família (hoje abandonada e invadida por malfeitores), do seu estranho amor à irmã (hoje casada com um marido rico), da outrora natureza exuberante (hoje ameaçada pelos interesses do capital), dos destinos humanos abortados pelo tempo.

Repontam no romance alegorias do esgotamento de certos valores modernos que marcaram a arquitetura e o urbanismo em seu modelo racionalista, universalista, tecnocêntrico e padronizado, a la Corbusier. De fato há páginas marcantes sobre a luta entre modelos de cidade e de modernidade que se apresentam como a luta entre uma casa com design contemporâneo e um teimoso fícus. A casa da irmã, projetada para banir a natureza pujante de seu entorno, remete a um mundo que tenta afastar tudo que é desordem: pobreza, caos, liberdade, vida. O vidro e o aço da mansão sufocam a árvore resistente que finalmente é cortada e impedida de afrontar rizomaticamente a disciplina espacial planejada.

Em Estorvo, o próprio título cabe ao protagonista, que ilustra certo tipo humano que compõe a vasta multidão de marginalizados e figuras 
liminares no tecido da grande cidade capitalista. O herói anônimo de Estorvo, rapaz de classe média, mais que fugir de um obstáculo que surge inesperadamente à sua porta, representa ele mesmo um problema para sua família, para a sua classe, para aqueles com quem convive. Permeável às possibilidades de seu corpo em suas andanças nos espaços da cidade, orientando-se vagamente por pedaços de lembranças ou sonhos, avesso às opções convencionais (casamento, filhos, emprego), entrega-se ao ir e vir interminável pelos espaços físicos e sociais mais diversos. Não sendo favelado, nem ricaço, nem da zona sul, nem da zona norte, convivendo com traficantes e vips, o herói veste as referências do espaço e das pessoas que cruza, de forma transitória.

Evocando a liquidez das relações contemporâneas (BAUMAN, 2004), infensas ao compromisso e às obrigações duradouras, em certo momento da intriga, o protagonista vê-se sintomática e incomodamente preso a uma mala:

\begin{abstract}
É noite e faz um calor abafado. A mala até que está leve, mas carregá-la é um incômodo, chama a atenção. Ponho no meio-fio e faço de conta que espero um táxi. Um táxi freia e eu saio andando com a mala, fingindo conferir a numeração dos edifícios. Dobro a esquina e tomo uma rua sem movimento; talvez um assaltante me livre da mala. Com o sono em dia e banho tomado, poderia andar por aí até amanhã, sem compromisso. Mas um homem sem compromisso, com uma mala na mão, está comprometido com o destino da mala. Ela me obriga a andar torto e depressa. (p.53)
\end{abstract}

Chama à atenção a sua incapacidade de estabelecer vínculos ou compromissos e de observar as vastas interdições que organizam o mundo social. De fato o herói dá a impressão de transitar entre espaços antagônicos, incapaz de demarcar as fronteiras usuais da realidade: trabalho honesto/crime, ricos/pobres, presente/passado, vida real/sonho. Se em Memórias de um Sargento de Milícias, podia-se falar numa dialética da malandragem, emblemática do trânsito maleável entre os altos e os baixos estratos da sociedade brasileira imperial, no romance de Chico Buarque, tese e antítese não se resolvem numa síntese apaziguadora, mas giram numa forma circular: o texto de fato é estruturado de forma que a situação inicial e a final coincidem. O protagonista vê seu mundo sem solução ou finalidade, moto-contínuo que, de forma alegórica, evoca o modo de subjetivação na cultura do consumo no Brasil.

Em J oão Gilberto Noll, vê-se ainda mais forte a tentativa de superar a escritura romanesca realista-psicológica tradicional. Descrições minimalistas e falta de ênfase no psicológico tornam suas personagens estranhas. Em Hotel Atlântico, sabe-se pouco sobre o protagonista. Por que está de passagem o tempo todo? Para onde vai? Que deseja? Quem é ele, afinal? As demais personagens também apresentam esse perfil rarefeito, surgindo e desaparecendo subitamente, antes que o leitor 
construa alguma idéia coerente acerca do mundo intencional desses atores. Desta forma, expectativas usuais de interpretação sobre razões, motivações e crenças das personagens ou mesmo sua função no enredo são abortadas e o leitor é conduzido velozmente para cenários e acontecimentos estranhos e inesperados. A verossimilhança e a motivação deixam de ser objeto de controle, emergindo situações ambíguas e insólitas que deixam ao leitor a tarefa, às vezes incômoda, de catar um sentido lógico às ações e construir uma interpretação global, contra a maré das convenções. $\mathrm{Na}$ intriga de Hotel Atlântico, o protagonista locomove-se de cidade em cidade, o destino decidido a cada instante e ao sabor dos encontros e experiências casuais: aqui o sexo com a recepcionista do hotel, ali, a conversa com a americana suicida, mais adiante, a carona com estranhos que se tornam perseguidores; mais ao fim, uma hospitalização e amputação que surpreendem e desarmam o leitor. Chegamos a suspeitar da chave de leitura que empregamos até o momento.

O nomadismo contemporâneo também ganha visibilidade nos textos de Caio Fernando Abreu, cujos personagens tendem a transitar incessantemente por ruas, bares, clubes, vitrines, shopping centers, estações e países, quase sempre na qualidade de "estranhos estrangeiros" (GERMANO; LIMA, 2007). Figuras liminares ou marginais homossexuais, desempregados, viciados, solitários - muitos heróis de Caio Abreu perambulam nos espaços da cidade à cata de sexo e amor. Ambivalentemente, essa busca do Outro dá-se na tensão entre o medo do compromisso (levando-os às múltiplas relações efêmeras e casuais) e o desejo romântico de um amor ou aspiração relativamente duradouro. A voz do narrador do conto "O rapaz mais triste do mundo", de Os dragões não conhecem o Paraíso, ilustra o sentimento de perda de referências num tempo em que nem a religião, nem as ideologias, nem as relações comunitárias fornecem suficiente base para a identificação dos indivíduos. Neste tempo em que o sentido naufragou, resta a errância do corpo e o vazio espiritual:

Eu quero ler poesia, eu nunca tive um amigo, eu nunca recebi uma carta. Fico caminhando à noite pelos bares, eu tenho medo de dormir, eu tenho medo de acordar, acabo jogando sinuca a madrugada toda e indo dormir quando o sol já está acordando e eu completamente bêbado. Eu nasci neste tempo em que tudo acabou, eu não tenho futuro, eu não acredito em nada - isso ele não diz, mas eu escuto, e o homem em frente dele também, e o bar inteiro também. (ABREU, 1988: 63).

Nem sempre o trânsito por espaços urbanos é tão veloz, nem a narração tão ligeira. Noutra linha de refiguração da experiência urbana, esta visão corrida da cidade dá lugar a outros tipos de caminhada, que nostalgicamente evocam os passeios do flâneur na cidade que outrora se 
industrializava. Desta vez, a figura serve para dizer o que foi soterrado na paisagem da cidade e na sua memória. O melhor exemplo é "A arte de andar nas ruas do Rio de Janeiro", de Rubem Fonseca, longo conto reunido em Romance Negro, de 1992. A cidade do Rio de Janeiro, o centro da cidade, é o cenário por onde passeia o escritor solitário que tenta ensinar prostitutas a ler e que redige um livro sobre a arte de andar nas ruas decadentes da Cidade Maravilhosa. Augusto Epifânio é um cavalheiro e um escritor moderno, recusando os excessos comerciais que degradam as paisagens humanas, os espaços físicos e a obra de arte. Resiste ingloriamente ao aviltamento da cidade, funcionando como guardião que recolhe as lembranças e as protege do esquecimento. Esse escritor andarilho encarna o homem moderno, ou melhor, os valores modernos em declínio no fim do século XX. Como a firmar o aspecto caudaloso da memória e a lentidão do homem que contempla o mundo (sem apenas consumi-lo vorazmente), o texto diminui o passo e se alonga em mais de trinta páginas de andanças do escritor comprometido.

Augusto Epifânio corresponde ao colecionador à antiga, não o "coleccionador al revés" de que fala Sarlo (1994), este último caracterizando o indivíduo consumista do capitalismo pós-industrial. Encontrando valor na tradição, na memória de pessoas que morreram e nos velhos objetos, documentos e monumentos que guardam o passado, o protagonista contradiz o impulso dominante e incessante de adquirir e descartar e, em consequência, de esquecer e alterar a fisionomia da cidade. Em vez de colecionar objetos, o consumista típico é um colecionador de atos de aquisição; Augusto repudia esse modelo, residindo numa antiga chapelaria do centro, com ratos e objetos de estimação e velhos hábitos. Sarlo explica:

El colecionador de viejo tipo sustrae los objetos de la circulación y del uso para atesorarlos : ningún filatelista manda cartas con las estampillas de su colección; ningún apasionado de los soldaditos de plomo permite que um niño juegue com ellos; las cajas de fósforos de una colección no deben usarse. El coleccionista tradicional conoce el valor de mercado de sus objetos (porque ha pagado por ellos) o conoce el tiempo de trabajo coleccionístico que ha invertido em conseguirlos si no han llegado a él a través de la venta y la compra. Pero también conoce el valor, digamos sintáctico, que esos objetos tienen em la colección: sabe cuáles le faltan para completar uma serie, cuáles son los que de ningún modo pueden ser canjeados por otros, qué historia está atrás de cada uno de ellos. Em la colección tradicional, los objetos valiosos son literalmente irreemplazables aunque un coleccionista pueda sacrificar alguno para conseguir outro vás valioso todavia. (2006: p. 25-26)

Como o clássico flâneur, que resiste à perda das tradições e do passado e a ser engolido eternamente pelo novo, Augusto encarna um tipo e um 
mundo em extinção. Não por acaso seu ofício é o das letras; é o ofício de encontrar um caminho e um sentido por entre as descontinuidades da cidade/sociedade mutante e de ensinar aos iletrados o poder da narrativa - isto é, da história - de produzir sentido pessoal e coletivo. O texto de Rubem Fonseca encontra-se entre aqueles que pensam a cidade e a sociedade contemporâneas na perspectiva nostálgica da perda e a arte em seu papel crítico e civilizador. Meio fora e meio dentro do seu próprio tempo, partícipe e opositor das novas práticas urbanas, o protagonista tenta descrever a "arte de andar" nas ruas da metrópole, agora sem as antigas referências, sem os velhos nomes, usos e símbolos do espaço. Tal arte de ler, lembrar e usufruir a cidade construída sobre ruínas é orientada pela busca de "uma arte e uma filosofia peripatéticas que o ajudem a estabelecer uma melhor comunhão com a cidade. Solvitur ambulando". (FONSECA, 1994: p. 600). Seu olhar é de quem lembra o passado e busca conexões entre o velho e o novo, crente ainda na possibilidade de narrar a cidade:

\begin{abstract}
Augusto tem um destino naquele dia, como aliás em todos os dias que sai de casa; ainda que pareça deambular, nunca anda exatamente ao léu. Pára na rua do Teatro e olha para o sobrado onde sua avó morava, em cima do que agora é uma loja que vende incenso, velas, colares, charutos e outros materiais de macumba, mas que ainda outro dia era uma loja que vendia retalhos de tecidos baratos. Sempre que passa ali lembra-se de um parente- a avó, o avô, três tias, um tio postiço, uma prima. ( $p$. 604)
\end{abstract}

Noutros escritos de Rubem Fonseca, o espaço da metrópole e a cultura do consumo podem receber tratamento expressionista, tornando dramáticas e chocantes as cenas de tensão que envolvem os habitantes da cidade injusta. Deformando o real ao ponto da caricatura e do grotesco, a experiência urbana associa-se ao mundo do crime, da violência, das perversões, das patologias, dos excrementos e secreções que impactam o leitor, inibindo qualquer aspiração a uma fruição amena do texto. A deformação tem o efeito de realçar o real "vivido", especialmente as terríveis contradições do panorama social brasileiro. Este é o caso dos contos "O cobrador", "Feliz ano novo", "O outro", "Passeio noturno (Parte I)", "Passeio noturno (Parte II)", escritos na segunda metade da década de 70. N' O cobrador, o narrador em primeira pessoa conta como cansou de ser desfalcado das coisas boas da vida e que agora apenas cobra aquilo que é de seu direito: dentes, casa, colégio, namorada, aparelho de som, sorvete, bola de futebol, sapato, automóvel. História do excluído que vai à forra, o texto causa impacto ao expor cruamente o sentimento de quem se encontra às margens do consumo, mas que é obrigado a ver a todo instante o que lhe escapa. Seu lema é "quando não se tem dinheiro, é bom ter músculos e ódio" (p. 495). Esse ódio torna-se programático: 
Fico na frente da televisão para aumentar meu ódio. Quando minha cólera está diminuindo e eu perco a vontade de cobrar o que me devem eu sento na frente da televisão e em pouco tempo meu ódio volta. Quero pegar um camarada que faz anúncio de uísque. Ele está vestidinho, bonitinho, todo sanforizado, abraçado com uma loura reluzente, e joga pedrinhas de gelo num copo e sorri com todos os dentes, os dentes dele são certinhos e são verdadeiros, e eu quero pegar ele com a navalha e cortar os dois lados da bochecha até as orelhas, e aqueles dentes branquinhos vão todos ficar de fora num sorriso de caveira vermelha (p. 494).

Em Feliz Ano Novo, a desigualdade perversa, obscenamente exposta na publicidade e no ethos da classe abastada, é abordada mediante o contraste entre o estilo de vida de quem pode e quem não pode ter uma festa de Reveillon. Após saberem pela TV da explosão de vendas de comida, bebida e roupas ricas para as festas de fim de ano, o narrador e mais alguns comparsas resolvem invadir uma casa e assaltar os grã-finos numa dessas festas. O resultado é uma carnificina contada de forma banal pelo narrador, como a evocar a inevitável deterioração moral de uma sociedade que explora e é explorada. Os explorados saem da invisibilidade em que normalmente se encontram e definem o jogo a seu favor por meio da violência extrema.

$\mathrm{Na}$ perspectiva das elites dominantes, os contos "O outro" e "Passeio Noturno (l e ll)" também figuram a tensão entre os altos e baixos estratos sociais, levando ao paroxismo a violência da segregação entre ricos e pobres. Sempre explorando a perversão de uma cultura consumista sem limites éticos, nestes contos, Rubem Fonseca examina os efeitos patológicos dos processos de subjetivação atuais sobre os indivíduos que estão nas camadas superiores. No conto "O outro", o relato do narrador, um executivo estressado, informa como a segregação das diferenças no espaço urbano aliada a um ritmo avassalador e desumano de produção contribui para a deformação das percepções interpessoais e das relações com a alteridade. Escravizado ao tempo produtivo cada vez mais faltoso, o executivo é incapaz de enxergar com acuidade o pedinte que o assedia. Sua visão é superficial, marcada por medo e vontade de livrar-se daquela presença perturbadora, que o faz descrever o mendigo como um homem branco, alto, forte e ameaçador. À medida que o pedinte retorna, cada vez mais insistente e apelando para a sua responsabilidade (ou culpa) de homem rico, sua presença torna-se insuportável. O executivo sente-se "perseguido", adoece do coração, afasta-se do emprego. Cada encontro com o sujeito recrudesce a percepção do narrador de que está sendo ameaçado - passa então a descrever o olhar do pedinte como "cínico e vingativo". O desfecho, que ocorre após novo assédio, quando o narrador já apresenta melhoras de sua saúde, é 
exemplar da fragilização das relações de alteridade engendradas num espaço urbano que estimula a paranóia, o medo, a individualidade:

\begin{abstract}
Voltei, abri a porta e ele ao me ver disse "não faça isso, doutor, só tenho o senhor no mundo". Não acabou de falar, ou se falou, eu não ouvi, com o barulho do tiro. Ele caiu no chão, então vi que era um menino franzino, de espinhas no rosto, e de uma palidez tão grande que nem mesmo o sangue, que foi cobrindo a sua face, conseguia esconder. (p. 414)
\end{abstract}

Os relatos impressionantes dos "passeios noturnos" de outro executivo mantém a mesma linha de exploração da temática da incomunicabilidade que aliena os sujeitos dentro dos lares, no trabalho e nas ruas. O executivo cansado após um dia intenso de trabalho "relaxa" de sua rotina estressante em passeios de carro que não têm outra finalidade senão atropelar e matar pedestres incautos. Espécie de alegoria das patologias da sociedade de consumo - que tem no automóvel símbolo máximo de autonomia, liberdade, prazer, individualidade e superioridade - o texto reforça a perda de qualquer sentido de civilidade associado à vida urbana. $\mathrm{O}$ executivo tem horror à cidade ("cidade que tem mais gente que moscas") e indiferença e certa aversão irônica à família interesseira ("Meu filho me pediu dinheiro quando estávamos no cafezinho, minha filha me pediu dinheiro na hora do licor. Minha mulher nada pediu, nós tínhamos conta bancária conjunta"). Apegado não às pessoas, mas ao seu automóvel, enfrenta o tédio e o isolamento existencial mediante a adrenalina de destruir, com precisão, o outro desconhecido que caminha pelas ruas.

\title{
III. Considerações (quase) finais
}

são paulo relâmpagos (são paulo é o lá-fora? É o aqui-dentro?)

(RUFFATO, 2007: 100)

O poder de atração e repulsão da cidade tem fornecido temas e posturas que atravessam profundamente a literatura, na qual a cidade aparece mais como metáfora do que como lugar físico. [...] E, se o modernismo é uma arte especificamente urbana, em parte é porque o artista moderno, tal como seus semelhantes, foi capturado pelo espírito da cidade moderna, que em si é o espírito de uma sociedade tecnológica moderna. (BRADBURY, 1989: 77)

As ficções urbanas produzidas por escritores brasileiros contemporâneos tais como Chico Buarque, Caio Abreu, Rubem Fonseca, João Gilberto Noll e Luiz Ruffato encarnam as novas sensibilidades em relação à vida na metrópole atual, bem como as possibilidades e limites envolvidos na sua expressão literária. Tal ficção revela a dificuldade de ordenar de forma totalizante as múltiplas vivências que compõem a sociedade e a cultura no 
capitalismo multinacional, especialmente em termos das grandes cidades multiculturais não plenamente desenvolvidas. Cientes da limitação da expressão romanesca, os escritores buscam formas de figuração das vivências e sensibilidades atuais que tornem visíveis os incessantes encontros e confrontos dos discursos e poderes que atravessam a metrópole.

A presente leitura desses textos procura assinalar como a condição tardomoderna está inscrita nos textos da ficção contemporânea, não somente na sua contextualização, mas na sua estrutura profunda, na sua forma. Além de explorar a experiência urbana atual no plano temático, os textos revelam as dificuldades de comunicação entre o escritor e seu leitor em sua tarefa de dizer a cidade, a modernidade e suas formas de subjetivação. Os textos muitas vezes apresentam uma forma fragmentada, de modo a descrever a babel das cidades globalizadas. Essa literatura assinala a dificuldade de se pensar a experiência urbana de forma unívoca e abrangente, seja em termos conceptuais, seja ideologicamente. $O$ escritor se restringe a apresentar algumas leituras alegóricas da cidade, alguns "pedaços", "passeios", não o conjunto sócioantropológico total como, por exemplo, procurou fazer a literatura de problemática nacional. A "literatura de subtração", usando o termo de Alexandre Faria - "a que detecta mais as ausências que as presenças" figura exatamente a cidade sem corpo, difícil de fixar em palavras.

As imagens de ilegibilidade e o tom de melancolia dos ficcionistas tornam a megacidade objeto do discurso poético e um problema a exigir interpretação. Neste sentido, conhecer o imaginário urbano dos escritores é desenterrar possibilidades urbanas que não vingaram, mas que se mantêm como virtualidades. Onde a experiência imediata encara a dispersão, a narrativa literária está lá para sugerir um nexo imaginário. Mesmo diáfanos esses nexos mostram-se particularmente importantes hoje quando nos perguntamos frequentemente, como uma personagem de Ruffatto, "tanto sacrifício vale a pena?" ou

\author{
para que \\ se tudo acaba \\ tudo \\ tudo se perde num átimo \\ o sujeito no farol se assusta \\ atira \\ o cara sangrando sobre o volante o carro ligado \\ o povo puto atrás dele \\ ele \\ atrapalhando o trânsito \\ o povo puto atrás dele \\ buzinando \\ buzinando \\ puto atrás dele. ( p.77)
}


No contexto de perplexidade, cansaço e medo onipresentes na metrópole, as ficções representam não apenas modo de elaborar o sofrimento urbano de cada dia, mas sinalização para uma outra cidade possível.

\section{Referências Bibliográficas}

ABREU, C. F. Os Dragões não conhecem o Paraíso. São Paulo: Companhia das Letras, 1988.

BAUMAN, Z. Amor líquido: sobre a fragilidade dos laços humanos. Rio de Janeiro: Jorge Zahar, 2004.

BUARQUE, C. Estorvo. São Paulo: Companhia das Letras, 1991.

BRADBURY, M.; McFARLANE, J. Modernismo: guia geral. São Paulo: Companhia das Letras, 1989.

BENJ AMIN, W. Sobre alguns temas em Baudelaire. In: Walter Benjamin, Max Horkheimer, Theodor Adorno, Jurgen Habermas: Textos escolhidos (Coleção Os Pensadores). São Paulo: Abril Cultural, 1980.

CANCLINI, N. G. Consumidores e cidadãos: conflitos multiculturais da globalização. Rio de Janeiro: Editora da UFRJ , 2001.

FARIA, A. Literatura de subtração: a experiência urbana na ficção contemporânea. Rio de Janeiro, Papel Virtual, 1999.

FONSECA, R. Contos Reunidos. Organização de Boris Schnaiderman. São Paulo: Companhia das Letras, 1994.

FIGUEIREDO, V. F. de. Crise da narrativa e ilusionismo verbal. Revista Semear. Vol.7 (A situação da narrativa no início do século XXI). Disponível em: http://www.let.puc-rio.br/Catedra/revista/7Sem_17.html. Acesso em 22 abr. 2008.

FOSTER, H. O Retorno do Real. Tradução de Cláudia Valladão de Mattos. Concinnitas: Revista do Instituto de Artes da UERJ . Rio de Janeiro: vol. 1 (8), p. 25, 2005, pp.162-186. Disponível em: http://www.concinnitas. uerj.br/revs/rev8.html. Acesso em 20 jan. 2008.

GERMANO, I.; LIMA, D. M. de A. Nomadismo e solidão na cidade veloz: alegorias da compressão espaço-tempo na ficção de Caio Fernando Abreu. Rio de Janeiro, Anais do XIV Encontro Nacional da ABRAPSO, 2007. GOMES, R. C. A cidade moderna e suas derivas pós-modernas. Revista Semear. Rio de Janeiro: PUC, $n$. 4. Disponível em: http://www. let.puc-rio.br/catedra/revista/4Sem-03.html. Acesso em: 22 abr. 2004.

- Detetive de subtrações nos percursos urbanos da literatura. In: FARIA, A. Literatura de subtração: a experiência urbana na ficção contemporânea. Rio de Janeiro, Papel Virtual, 1999.

.Todas as cidades, a cidade: literatura e experiência urbana. Rio de Janeiro: Rocco, 1994. 
HARVEY, D. Condição Pós-Moderna: uma pesquisa sobre as origens da mudança cultural. São Paulo: Loyola, 1994.

KEOHANE, K. The revitalization of the city and the demise of J oyce's utopian modern subject. Theory, culture and society. London, Thousand Oaks and New Delhi: Sage Publications, v.19, n.3, 2002, p. 29-49.

LOBO, L. Richard Rorty e a importância do pós-moderno no contexto cultural brasileiro. Working paper CBS 21-01. Oxford: University of Oxford Centre for Brazilian Studies, 2001. Disponível em: http://www.brazil.ox.ac.uk/workingpapers/lobo21.pdf. Acesso em 22/04/2008.

NOLL, J. G. Hotel Atlântico. São Paulo: Francis, 2004.

OLINTO, H. K. Historiografia (literária) entre o passado e o presente. GT História da Literatura. Porto Alegre: PUCRS/ANPOLL, s/d. Disponível

em: http://www.pucrs. br/fale/pos/historiadaliteratura/gt/olinto.php.

Acesso em 22 abr. 2008.

PELLEGRINI, T. Clear enigma: Brazilian crime fiction and urban violence. Working paper CBS 69-05. Oxford: University of Oxford Centre for Brazilian Studies, $2005 . \quad$ Disponível em: http://www. brazil. ox.ac.uk/workingpapers/Pellegrini\% 2069. pdf.

Acesso em 22 abr. 2008.

PERRONE-MOISÉS, L. Altas literaturas: escolha e valor na obra crítica de escritores modernos. São Paulo: Companhia das Letras, 1998.

RUFFATO, L. Eles eram muitos cavalos. Rio de Janeiro: Record, 2007.

SARLO, B. Escenas de la vida posmoderna: intelectuales, arte y videocultura em la Argentina. Buenos Aires: Seix Barral, 2006.

SIMMEL, G. A metrópole e a vida mental. In: O. G. Velho. O fenômeno urbano. Rio de Janeiro: Jorge Zahar Editor, 1979. Originalmente publicado em 1900.

SUSSEKIND, F. Deterritorialization and literary form: Brazilian contemporary literature and urban experience. Working paper CBS 34-02. Oxford: University of Oxford Centre for Brazilian Studies. Disponível

em: http://www. brazil.ox.ac.uk/workingpapers/Sussekind34.pdf. Acesso em 22 abr. 2008.

\section{Endereço para correspondência}

I dilva Maria Pires Germano

Faculdade de Psicologia da Universidade Federal do Ceará-UFC, Av. da Universidade,

2853, Benfica, Fortaleza, CE. CEP: 60020-181

Endereço eletrônico: idilvapg@ufc.br

Recebido em: 06/06/2008

Aceito para publicação em: 02/02/2009

Editor responsável: Ariane Patrícia Ewald 


\begin{abstract}
Notas
* Doutora em Sociologia.

1 Considerando o limitado escopo deste trabalho, não exploraremos todas as possíveis classificações da literatura brasileira dita "pós-modernista" (se é que se pode reunir a profusão e o ecletismo de estilos atuais numa só rubrica), mas selecionar algumas obras escritas a partir da década de 1970 que abordam a experiência urbana brasileira e nessas, selecionar algumas constantes temáticas e formais. 2 Essa teorização foi realizada por Linda Hutcheon, Fredrick Jameson, Terry Eagleton e muitos outros. Para uma visão crítica dos estudos acadêmicos e do clima de declínio dos valores literários modernos, conferir Leyla Perrone-Moisés. Altas Literaturas (especialmente o capítulo "A modernidade em ruínas"). $\underline{3}$ Autores como Faulkner, Woolf, J oyce e outros já haviam explorado a impossibilidade de uma representação realista e objetiva, rejeitando o narrador onisciente, multiplicando os pontos de vista, fragmentando a narrativa, usando colagens e recursos como o fluxo da consciência, de modo a enfatizar como o real é percebido e não o que é percebido dele. 4 “Eles eram muitos cavalos/E morreram por esses montes, / Esses campos, esses abismos/Tendo servido a tantos homens/ Eles eram muitos cavalos/Mas ninguém sabe os seus nomes/ Sua pelagem, sua origem" ( O romanceiro da Inconfidência)
\end{abstract}

